\title{
Rheumatoid Factor Antibody IgM Measurement
}

National Cancer Institute

\section{Source}

National Cancer Institute. Rheumatoid Factor Antibody IgM Measurement. NCI

Thesaurus. Code C120654.

The determination of the rheumatoid factor antibody $\lg \mathrm{M}$ present in a sample. 